\title{
Measuring financial literacy: proposition of an instrument based on the Item Response Theory
}

\author{
Kelmara Mendes Vieira', Fernando de Jesus Moreira Júnior", \\ Ani Caroline Grigion Potrich"II
}

\begin{abstract}
Financial literacy is a complex and multidimensional phenomenon. Thus, building a financial literacy measure has been a challenge. This study seeks to contribute to this scenario by proposing a Financial Literacy measure. The three dimensions suggested by the Organization for Economic Co-operation and Development (OECD) are considered: financial education, financial attitude and financial behavior. For validation of the measurement, the questions were constructed and the instrument was applied in 1576 Brazilians, between November and December 2013. To evaluate the measurement, two models of the Item Response Theory were used, the unidimensional two-parameter logistic model for the Financial Knowledge scale and the Graded Response Model (GRM) for financial attitude and behavior. From the main items, five levels of financial literacy were constructed. The results pointed to the appropriateness of the proposed measure. The final instrument has thirteen questions of financial knowledge, six of financial attitude and twenty-four of financial behavior, which allow to identify the level of individual financial literacy in each of the three dimensions. From the ability scales, we found that $44.10 \%$ of respondents had average financial knowledge. In the attitude and behavior scales, the most representative level was also the median (ability between -0.5 and 0.5 ).
\end{abstract}

Keywords: Financial Literacy; Measuring; Item Response Theory; Scales; Behavioral Finance.

\footnotetext{
'Federal University of Santa Maria, Santa Maria, Brasil. E-mail: kelmara@terra.com.br.

"Federal University of Santa Maria, Santa Maria, Brasil. E-mail: fmjunior@smail.ufsm.br.

III Federal University of Santa Catarina, Florianópolis, Brasil. E-mail: anipotrich@gmail.com.
} 


\section{INTRODUCTION}

Throughout life, individuals take tens of thousands of financial decisions: expensive or cheap? Buy or save? Invest in savings, bonds or stocks? What is the risk of the business? What is the interest rate to pay? Use credit or debt? These are just some of the issues that constantly require the individual to be financially literate. Despite its importance for more responsible decision-making, several studies have pointed out that a large part of the world's population still suffers from financial illiteracy and that measures to solve this problem are urgent (LUSARDI; MITCHELL, 2011; ATKINSON; MESSY, 2012, OPLETALOVÁ, 2015). Technology and the integration of financial markets, while making financial products more accessible to more people, increases the speed and complexity of financial decisions to be made. In this context financial literacy is becoming an essential skill for full participation in society (OECD, 2015, 2017).

However, one of the major problems for the adoption of national financial literacy strategies has been the lack of a universal measurement model to indicate the level of financial literacy of individuals and consequently the priority focus of action in different population profiles. Without an adequate model for assessing the level of financial literacy, it becomes difficult to identify the themes and strategies to be adopted in different population groups.

In the last few years, some proposals for measuring financial literacy have arisen (KADOYA; KAN, 2019), such as the set of three questions developed by Annamaria Lusardi and Olivia Mitchell, which are commonly used in several studies and deal with interest rates, inflation and risk diversification (KNOLL, 2012), the research by Clark, Lusardi, and Mitchell (2015), which developed an instrument called FinLitSurvey with five questions, the annual National Financial Capability Study (NFCS, 2013), and the proposed scale the Organization for Economic Co-operation and Development (OECD) to measure financial literacy with nineteen questions (OECD, 2013). However, up to now, most of these proposals have focused efforts on the creation of measures, which still lack validation and psychometric assessment procedures. Much of the effort has been in creating the issues necessary to assess financial literacy, but little has been discussed about the capacity for discrimination and the difficulty of the issues, the level 
of informational completeness of the instruments and even the challenge of creating a scale that is capable of indicating the level of individual financial literacy.

Thus, the research problem is: How to properly evaluate the level of financial literacy of individuals? So this works aims to build an individual financial literacy measure. For this purpose it is proposed to use two models of Item Response Theory (IRT). The use of IRT to development scales of measures, with the determination of the items parameters of the chosen model is a universal trend and have been used extensively in the fields of educational (JÚNIOR, 2014) and psychological measurement (SZELES; FUSCO, 2013). The IRT in relation to the Classical Theory of Tests has as an advantage the makes use of more information (XUE; GEPP; O'NEILL; STERN; VANSTONE, 2018). The technique analysis of the characteristics of the items, such as discrimination and difficulty, and the estimation of the ability of individuals considering such characteristics.

Obtaining a model for assessing the level of financial literacy is important both for governments and for different financial agents. Governments need to find effective approaches to improving the level of financial literacy of the population by creating or perfecting national strategies to provide learning opportunities at different levels of education (ATKINSON; MESSY, 2012). Financial agents need to identify the financial literacy of their clients/investors to develop differentiated strategies and products. And the global financial system, which provides more and more elaborate international products and operations, needs increasingly literate investors to be able to make complex financial decisions.

In addition to this introduction, the article presents in section 2 the concepts and instruments proposed by the literature for the theme of financial literacy. Then, in section 3 there is the method, which specifies the sample, the instrument and the analysis models. Section 4 presents the results of the estimated models for the three dimensions that were financial literacy (knowledge, attitude and behavior), and the section 4 concludes the study. 


\section{FINANCIAL LITERACY: CONCEPTS AND INSTRUMENTS}

The term financial literacy does not have a single and simple definition in the literature, since it is a complex subject and encompasses a broad set of aspects. Although there are various definitions and dimensions for financial literacy, those developed by the OECD draw attention for their representativeness, which defines financial literacy as a combination of conscientiousness, knowledge, skill, attitude and behavior that are necessary to make sound financial decisions and ultimately attain individual financial well-being (OECD, 2015). Thus, the instrument for measuring financial literacy used by the OECD encompasses three dimensions: financial education or financial knowledge, financial behavior and financial attitude.

These three dimensions have their own definitions and are interrelated. Firstly, financial knowledge, also known as financial education, is a method in which people perfect their understanding of concepts and risks of financial products, thus being able to develop the skills and confidence necessary in making fundamental and safe decisions $(O E C D, 2017)$. Financial knowledge is essential to determine whether the individual is financially literate (ATKINSON; MESSY, 2012) and prepare them to make better choices, avoid pitfalls, identify the best places to get help, and assist in decision making (BUCHER-KOENEN; LUSARDI; ALESSIE; VAN ROOIJ, 2016)

However, financial knowledge alone is not sufficient for the effective management of finances, as the influence of financial knowledge on behavior is measured trough the financial attitudes. Shockey (2002) defines financial attitudes as a combination of concepts, information and emotions about learning, which results in a readiness to react favorably. With this, the development of attitudes can be the result of the direct experience of an individual, resulting from their exposure or their conditioning to the treated content (FAZIO; EISER; SHOOK, 2004). It can be developed by means of feelings, emotions or momentary opinions, or even evolve to a habitual position that can influence in the long term the behavior of someone (QFINANCE, 2013).

However, it is not enough just to have the financial knowledge and attitudes to stabilize financially, since in order to put it into practice, in addition to learning the concepts and the readiness to act, recognition of your financial situation is 
indispensable. According to Pietras (2014), by uniting such dimensions, the individual will be able to operate his expenditures, gains and investments that have been and will be realized, becoming interested in money and identifying the opportunities in order to be always expanding his financial intelligence, respecting its characteristics and its potentialities. In this context, financial behavior is revealed as the ultimate dimension of financial literacy, which according to the OECD (2013) is an essential and undoubtedly the most important element among the three, since it is behavior that financial imbalance.

However, although conceptually defined, still a major challenge for conducting research on financial literacy is the difficulty in determining the best way to measure it (LUSARDI; MITCHELL, 2014, POTRICH et al., 2015a). According to Schmeiser and Seligman (2013), the usual issues for measuring it have not been rigorously tested to ensure that they are accurately measuring the level of financial literacy of individuals.

The OECD points out that the correct measurement of financial literacy should be based on a range of knowledge and skills associated with developing the capacity to deal with the financial demands of everyday life in a contemporary society (OECD, 2013). In addition to the OECD proposal, other researchers around the world have also tried to develop models to measure financial literacy. An instrument is the FL-ABK (financial literacy - attitude, behavior and knowledge), developed by Shockey (2002) to analyze the respondents' attitudes, behaviors and financial knowledge. Other instruments measure the dimensions of financial literacy separately, as is the case with O'Neill and Xiao (2012) with a quiz called the Financial Fitness Quiz, which consists of twenty questions describing the frequency of performing best practices for an effective financial management, that is, evaluate the financial behavior of individuals in three aspects: the budget, spending and savings.

The financial knowledge dimension is the focus of the Klapper, Lusardi and Panos (2013) instrument, which included four financial literacy issues, covering compound interest rates (two questions), inflation (one issue), and sales discounts (one issue). Similarly, Van Rooij, Lusardi and Alessie (2011) developed an instrument that is based only on the dimension of financial knowledge, being composed of five questions 
treated as items of basic knowledge, which measure the numerical skills and the understanding of concepts such as inflation, simple interest, compound interest and the value of money over time, and eleven advanced knowledge issues that address knowledge related to complex financial instruments such as stocks, bonds and mutual funds, and understanding of concepts such as the diversification of risk and trade-off between risk and return. Chen and Volpe (1998) evaluated financial literacy with thirtysix multiple-choice questions about knowledge of personal finance in savings, loans, insurance and investment. Lusardi Oggero and Yakoboski (2017) developed the P-Fin Index (Personal Finance Index) This index measures the knowledge and understanding that enable conscious financial decision-making and effective management of personal finances through 28 questions.

It is thus perceived that several instruments have been proposed, but there is no consensus in academia regarding what instruments should be used to measure financial literacy (POTRICH; VIEIRA; MENDES-DA-SILVA, 2016a), some of them encompassing only one of the three dimensions advocated by the OECD. In addition, the central focus of these studies was on the development of the issues that should be used for the measurement of financial literacy. Therefore, the way to construct an adequate financial literacy instrument is still through the application of appropriate validation techniques that allow identifying the importance of the issues already proposed, up to the level of information completeness of the instruments, with a view to obtaining a model capable of identifying the level of individual financial literacy.

\section{METHOD}

The sample consists of 1576 valid instruments applied between November and December 2013. To measure the level of financial literacy, the measure proposed by Potrich et al. (2015) that contemplates the three constructs suggested by the OECD (2013): Financial Knowledge, Financial Attitude and Financial Behavior. Financial Knowledge was constructed based on multiple choice questions adapted from Van Rooij, Lusardi and Alessie (2011), OECD (2013), Klapper, Lusardi and Panos (2013) and National Financial Capability Studies (NFCS, 2013). It consists of thirteen questions 
aimed at exploring the respondent's level of knowledge regarding inflation, interest rate, time value of money, risk, return, diversification, stock market, credit and government bonds. For each of the thirteen questions of Financial Knowledge was assigned value equal to 1 for the correct answer and value equal to 0 for the incorrect ones.

To measure the financial attitude, the questions were adapted from Shockey (2002) and OECD (2013). The scale of the financial attitude, composed of ten likert fivepoint questions, aims to identify how the individual evaluates his financial management. The more the respondent disagrees partially and totally with the statements made, the better his financial attitude will be. To measure the behavior maintained by the respondents, the measures proposed by Shockey (2002), O'Neill and Xiao (2012) and OECD (2013) were used. The scale, consisting of twenty-seven likert fivepoint questions assesses the level of financial behavior of individuals. The greater the respondent's frequency in the statements made, the better his behavior in managing his finances.

Among the several mathematical models used in the IRT applications, this study will use the unidimensional two-parameter logistic model (2PL) (BIRNBAUM, 1968) and the Samejima Graded Response Model (GRM) (1969). The 2PL is suitable for adjusting polyatomics items with a single correct response option, as is the case with the Financial Knowledge scale. The 2PL model was chosen once the instrument has the "I do not know", which justifies the non-analysis of the probability dimension of randomization. The Model of Samejima (1969) is applied in polyatomic scales, such as the Attitude and Financial Behavior scales.

Mathematically, THE 2PL is given by:

$$
P\left(U_{i j}=1 \mid \theta_{j}\right)=\frac{1}{1+e^{-D_{a i}\left(\theta_{j}-b_{i}\right)}}
$$

$i=1,2, \ldots$, I e $j=1,2, \ldots, n$ 
where:

$\mathrm{U}_{\mathrm{ij}} \mathrm{i}$ a dichotomous variable (assumes the value 1 when the individual $\mathrm{j}$ answers correctly the item i, or assumes the value 0 , otherwise);

$\theta_{j}$ is the latent trait value (ability parameter) of the individual $\mathrm{j} ;$

$P\left(U_{i j}=1 \mid \theta_{j}\right)$ is the probability that individual $j$ correctly responds to item $i$, given that he has ability $\theta_{\mathrm{j}}$, that is, is the appropriation of correct answers of item $i$ of individuals of the population with ability $\theta_{\mathrm{j}}$;

$a_{i}$ is the discrimination (or slope) parameter of item $i$;

$b_{i}$ is the difficulty (or position) parameter of item $i$;

$D$ is a constant scale factor, equal to 1 if the parameters of the items are estimated logistic metric, or equal to 1.7 , if the parameters of the items are estimated in the metric of the normal ogive;

$e$ is the known mathematical constant equal to 2.718281 ... (Euller number); $i$ is the total number of items;

$n$ is the total number of individuals in the sample.

The parameter $a_{i}$ measures the discrimination of the item, where low values of $a_{i}$ indicate that the item has little power of discrimination, that is, the probability of an individual answering the item correctly is approximately the same for individuals with low or high knowledge. The high values of ai indicate that the item has great power of discrimination, dividing the individuals practically into two groups: those with abilities below the value of $b_{i}$ (with low probability to hit the item), and those with abilities above value of $b_{i}$ (with high probability to hit the item). There is no exact value of $a_{i}$ to decide whether an item discriminates well or not. Baker (2001) establishes a classification table where values from 0.01 to 0.34 are very low, from 0.35 to 0.64 are low, 0.65 to 1.34 are moderate, 1.35 to 1.69 are high, and greater than 1.70 are very high. 
The parameter $b_{i}$ represents the degree of difficulty of the item, that is, the higher its value, the more difficult the item and individuals with high skill will have a good probability to hit it. Mathematically, $b_{i}$ can assume any value between -1 and +1 , however, for very high or low values; the item may not be adequate, with values between -3 and 3 being usual, in the scale with mean zero and standard deviation equal to one.

The relationship between the expected response of the item and the latent trait of the subject is known through the Item Characteristic Curve (ICC). The curve shows the influence of the parameter ai (discrimination power) on the curve slope and the parameter bi (item position on the scale). The $X$ axis indicates the latent trait value (ability), considering a scale with mean 0 and standard deviation 1, while the $Y$ axis indicates the probability of the individual $j$ to respond positively to the dichotomous item $i$, since he has ability $\theta_{j}$. It is also possible to analyze the amount of information that an item provides for the latent trait measurement. The Item Information Function evaluates the information provided by each item and reflects the item quality. You can also estimate the Test Information Function which is the sum of the information provided by each item that composes the instrument.

When it is necessary to estimate the parameters of the skills and the items, as in this work, one can use the maximum likelihood method and jointly estimate the parameters of the items and the abilities of the individuals; or in two steps, first the estimation of the parameters of the items and, then, the estimation of the abilities.

After the estimation of the parameters, the scale construction is sought. In this work, we chose the methodology proposed by Beaton and Allen (1992), in which we try to identify, if there is one, at each level of the scale, whose power of discrimination is situated around this level and to use these items to describe what students whose proficiencies are close to this level know and are able to do. In order to select the anchor items, the selection criteria proposed by Beaton and Allen (1992) were used:

There are two consecutive anchor levels $Y$ and $Z$ with $Y<Z$. A given item is anchor for level $Z$ only if the 3 conditions below are satisfied simultaneously: 


$$
\begin{aligned}
& \mathrm{P}(\mathrm{U}=1 \mid \theta=Z) \geq 0,65 \\
& \mathrm{P}(\mathrm{U}=1 \mid \theta=\mathrm{Y}) \leq 0,50 \\
& \mathrm{P}(\mathrm{U}=1 \mid \theta=\mathrm{Z})-\mathrm{P}(\mathrm{U}=1 \mid \theta=\mathrm{Y}) \geq 0,30
\end{aligned}
$$

Thus, for an item to be anchor at a particular anchor level of the scale, it needs to be answered correctly by a large proportion of individuals with this ability level and by a smaller proportion of individuals with the immediately preceding ability level. In addition, the difference between the proportions of individuals with these ability levels who hit this item should be at least 30\%. Therefore, anchor items are items that characterize a point or level of the scales for which the vast majority of individuals at that level hit the item, whereas a considerable percentage of individuals at the level below the scale miss the item. And quasi-anchor items are items that meet two of the three established criteria.

The second model to be estimated for the financial attitude and behavior scales is Samejima's (1969) GRM. Mathematically, the model is defined by:

$$
\begin{aligned}
& P_{i, k}^{+}\left(\theta_{j}\right)=\frac{1}{1+e^{-D_{a i}\left(\theta_{j}-b_{i, k}\right)}} \\
& i=1,2, \ldots, I ; j=1,2, \ldots, n \text { and } k=0,1, \ldots, m_{i},
\end{aligned}
$$

Where, $b_{i}, k$ is the difficulty parameter of the $K$-th category of item $i$ and the other parameters are analogous to those previously defined.

The graded scale models that present an item with $\left(m_{i}+1\right)$ categories, $m_{i}$ difficulty values need to be estimated, in addition to the slope parameter of the item. In this work, as the Financial Attitude and Financial Knowledge scales present likert scale with five categories, four difficulty parameters and one discrimination are estimated. The parameter $b_{i, 1}$ indicates the inflection point of the curve of the first category (totally disagree). The $b_{i, 4}$ (totally agree), indicates the inflection point of the curve of the last category. The intermediate " $b_{i, k}$ " refers to the midpoint of the peaks between two adjacent categories (EMBRETSON; REISE, 2000). 
Similarly to the 2PL, the GRM was estimated by the maximum likelihood method and the conditions were used to identify the anchor items proposed for the $2 \mathrm{PL}$, but adapted to the GRM in which it is not verified if an item is an anchor, but if an item category is an anchor.

According the assumption of unidimensionality, the responses can be described by a model with only one latent trait (LIN, 2007). This assumption of the two models was verified by means of the Factor Analysis for categorical data, following the Reckase (1979) criterion, whereby the results may indicate a dominant factor when the first factor corresponds to at least $20 \%$ of the variance. For the factorial analysis with categorical data the Factor 9.2 program was used (LORENZO-SEVA; FERRANDO, 2013). For the estimation, software R version 64.3.3.3 ( $r$ core team, 2017) was used. For the 2PL the package was the Irtoys (PARTCHEV, 2016) and for the GRM the LTM (RIZOPOULOS, 2015). Package Itm fits the models using Marginal Maximum Likelihood Estimation (MMLE). The level of ability was estimated by the expected a posteriori (EAP) method.

\section{ANALYSES OF RESULTS}

The financial knowledge construct is composed of thirteen multiple-choice questions, which have been assigned a zero value for the wrong answers and one for the correct answers. The items in the scale and the frequency of correct and incorrect answers and those referring to the questions that the respondents were unable to answer, as well as the percentage of correct answers, are shown in Table 01.

Table 1 - Frequency and percentage valid for the Financial Knowledge scale

\begin{tabular}{|c|c|c|c|c|}
\hline Item & Questions & Multiple-choice alternatives & Frequency & Percentage $^{1}$ \\
\hline \multirow{5}{*}{1} & Assume you have $R \$ 100.00$ in a savings & * More than $\mathrm{R} \$ 150.00$ & 883 & $56.75 \%$ \\
\hline & account at an interest rate of $10 \%$ per & Exactly $\mathrm{R} \$ 150.00$ & 432 & $27.76 \%$ \\
\hline & year. After five years, which is the value & Less than $\mathrm{R} \$ 150.00$. & 103 & $6.62 \%$ \\
\hline & you have in savings? Consider no & & & \\
\hline & $\begin{array}{l}\text { money has been deposited or } \\
\text { withdrawn. }\end{array}$ & Do not know. & 138 & $8.87 \%$ \\
\hline \multirow{4}{*}{2} & Assume Joseph inherits $R \$ 10,000.00$ & * Joseph. & 775 & $49.90 \%$ \\
\hline & today and Pedro inherits $R \$ 10,000.00$ & Peter. & 160 & $10.30 \%$ \\
\hline & in about 3 years. Because of & They are equally rich. & 337 & $21.70 \%$ \\
\hline & inheritance, who will get richer? & Do not know. & 281 & $18.09 \%$ \\
\hline
\end{tabular}


Imagine that the interest rate on your savings account is $6 \%$ per year and the inflation rate is $10 \%$ per year. After one

More than today.

Exactly the same.

* Less than today.

147

52

$9.53 \%$

year, how much you will be able to buy

with money from that account? Consider no money has been deposited or withdrawn.

Assume that in 2018 your income will double and the prices of all goods also will double. In 2018, how much will you be able to buy with your income?

Do not know.

367

$23.80 \%$

\begin{tabular}{ccc} 
More than today. & 216 & $13.84 \%$ \\
* Exactly the same. & 990 & $63.42 \%$ \\
Less than today. & 192 & $12.30 \%$ \\
Do not know. & 163 & $10.44 \%$ \\
\hline Savings account. & 415 & $26.65 \%$ \\
* Stocks. & 424 & $27.23 \%$
\end{tabular}

510 years), which asset does usually offer higher return?

Government securities.

307

$19.72 \%$

Do not know.

$411 \quad 26.40 \%$

Savings account.

$64 \quad 4.10 \%$

Usually, which asset has the highest fluctuations over time?

* Stocks.

1124

$72.05 \%$

Government securities.

72

$4.62 \%$

Do not know.

300

$19.23 \%$

When an investor distributes his

7 investments among different assets, the risk of losing money:

Increases.

$298 \quad 19.16 \%$

* Decreases.

892

Remains unchanged.

65

$57.36 \%$

Do not know.

300

$4.18 \%$

* True.

1001

$19.29 \%$

A loan with maturity of 15 years usually requires higher monthly payments than

8 a 30-year loan, but the total amount of interest paid at the end of the loan will be lower. This statement is:

Assume you took a loan of $R \$ 10,000.00$

9 to be paid after one year and the total cost with interest is $R \$ 600.00$. The interest rate you will pay on this loan is:
$64.04 \%$

$19.51 \%$

False. $\quad 305 \quad 19.51 \%$

Do not know.

257

$16.44 \%$

$0.3 \%$

$0.6 \%$.

21

$1.35 \%$

$3 \%$.

217

$13.96 \%$

* $6 \%$.

53

$3.41 \%$

$63.90 \%$

993

Do not know.

$17.37 \%$

Assume you saw the same television at * Buying in shop A (discount of two different stores for the initial price

$R \$ 150.00)$.

270

$90.00 \%$

of $\$ 1,000.00$. The Shop A offers a Buying in shop B (discount of

discount of $R \$ 150.00$, while shop $B$

$10 \%)$.

1404

$4.10 \%$

offers a discount of $10 \%$. What is the best alternative?

Do not know.

92

$5.90 \%$

Imagine five friends receive a donation

11

of $R \$ 1,000.00$ and must equally divide

the money between them. How much

will any of them get?

100

* 200 .

1425

$0.89 \%$

1,000 .

45

$90.94 \%$

5,000 .

13

$2.87 \%$

$0.83 \%$

Do not know.

70

$4.47 \%$

An investment with high return rate will

have high risk rate. This statement is:

False.

$70.40 \%$

1094

$12.16 \%$

Do not know.

271

* True.

1378

$17.44 \%$

False.

67

$88.05 \%$

Do not know.

120

$4.28 \%$

cost of living rises. This statement is:

Note: ${ }^{1}$ The percentages considered correspond to the percentage of correct answers about the total answers. If a respondent did not respond, the percentage is automatically adjusted to the total. *Correct answer to the question. 
The items 1, 2, 3, 4, 8, 9, 10 and 11 are considered to belong to the basic Financial Knowledge, aiming to measure individuals' knowledge of everyday aspects such as simple and compound interest rates, time and simple mathematical operations. The only two items that presented a high success rate (above $80 \%$ ) were those that addressed simple mathematical operations, when asking about a simple division (\$ $1,000.00 / 5$ friends) and differentiating the best alternative between two discount options.

The second group of items $(5,6,7,12$ and 13) related to Advanced Financial Knowledge sought to explore proficiency in relation to more complex financial instruments. The two items that presented the highest percentages of success, deal with the oscillation in the profitability of actions over time (72.05\%) and the understanding of the relationship between risks and return (70.40\%). A low percentage of hit was observed in the item referring to the asset that offers the greatest return (27.23\%), and Financial Knowledge $(26,40 \%)$ of the individuals do not know how to respond.

It should be noted that the only item considered as Advanced Financial Knowledge that obtained a high percentage of accuracy was the understanding of the increase in the cost of living, caused by the increase in inflation (88.05\%). This result can be justified by the situation that Brazil experienced a few years ago, with high daily fluctuations in the inflation rate and the population witnessed the increase in the cost of living for this reason. Individuals usually tend to hit more the items whose themes can be seen and followed almost daily in the news or even experienced in situations of purchase of goods. When analyzing the number of correct answers per respondent, it was found that $2.22 \%$ of the respondents did not answer or did not know to answer any of the thirteen suggested items, and only $3.87 \%$ answered all the items, but more than half of the individuals answered correctly at least $66 \%$ of the questions.

Then, of the Financial Knowledge indicator was analyzed in light of the IRT. Due to the unidimensionality assumption, we chose to use the factorial analysis for categorical data. Figure 01 presents the screeplot for financial knowledge. 
Figure 1 - Screeplot of the Financial Knowledge

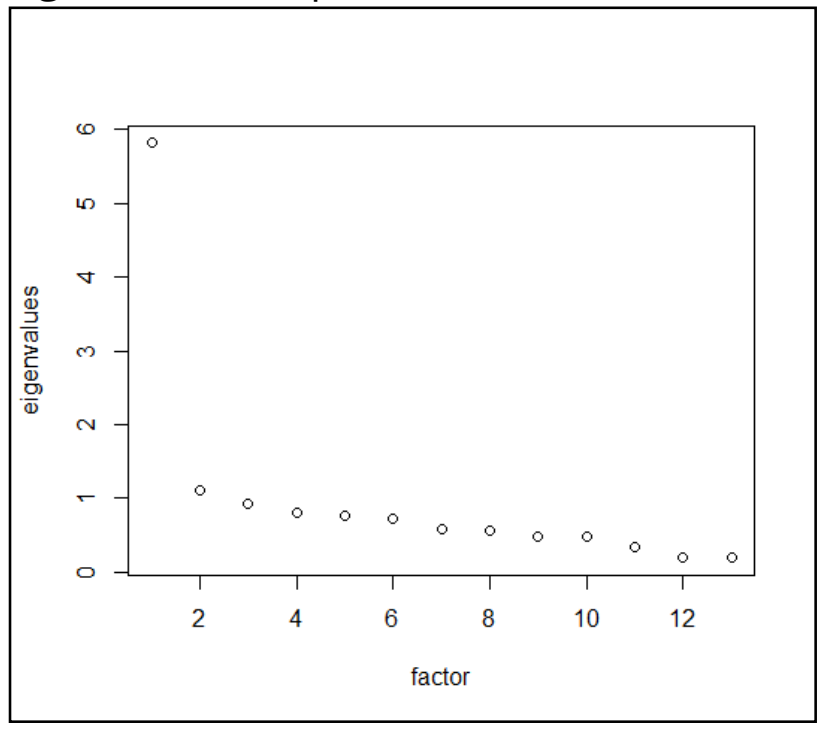

The first factor presented a percentage of explained variance of $44.71 \%$, a value well above the minimum of $20 \%$ suggested by Reckase (1979), as criterion of acceptance of the unidimensionality of the scale, thus proving the adequacy of 2PL. In MLU2 model, of the three items presented, it was chosen to exclude from the knowledge model item 2 (discrimination $=0.6258)$ and item 5 (discrimination $=0.433)$, since both presented a parameter of discrimination considered to be low, according to Baker (2001). Thus, Table 02 presents the results for the estimation with the remaining eleven parameters.

Table 2 - Coefficients and standard errors of the parameters of difficulty and discrimination for Financial Knowledge

\begin{tabular}{ccccc}
\hline Item & \multicolumn{3}{c}{$\mathrm{a}_{\mathrm{i}}$} & $\mathrm{b}_{\mathrm{i}}$ \\
\cline { 2 - 5 } & Coefficient & Standard Error & Coefficient & Standard Error \\
\hline 01 & 0.8232 & 0.0763 & -0.3328 & 0.0749 \\
03 & 1.6627 & 0.1244 & -0.4227 & 0.0488 \\
04 & 1.1065 & 0.0901 & -0.5827 & 0.0671 \\
06 & 1.7814 & 0.1301 & -0.7791 & 0.0565 \\
07 & 1.8777 & 0.1421 & -0.2143 & 0.0434 \\
08 & 1.1069 & 0.0905 & -0.06160 & 0.0683 \\
09 & 1.3702 & 0.1050 & -0.5158 & 0.0566 \\
10 & 2.6705 & 0.2534 & -1.4641 & 0.0712 \\
11 & 2.2237 & 0.2002 & -1.6625 & 0.0858 \\
12 & 1.4574 & 0.1115 & -0.7666 & 0.0616 \\
13 & 2.4125 & 0.2127 & -1.4064 & 0.0705 \\
\hline
\end{tabular}

As for discrimination, it is observed that item 01 is the one with the lowest discriminatory power, and items 11,13 and 10, respectively, are the ones with the 
highest discrimination, so, they discriminate the respondents among those with knowledge below the parameter $e$ those with knowledge above the parameter $b_{i}$.

Regarding the difficulty parameter, all items presented negative values. Thus, the smaller values the less difficulty of item. Therefore, item 11 and item 10 are the easiest items of the knowledge construct and item 7 is the most difficult. Such results are consistent with financial education studies, since questions 10 and 11 are considered Basic Financial Knowledge issues and question 7 is an advanced knowledge item. Figure 02 shows the characteristic curves of the items that make up the measure of Financial Knowledge.

Figure 2 - Item Response Function of the Financial Knowledge Items

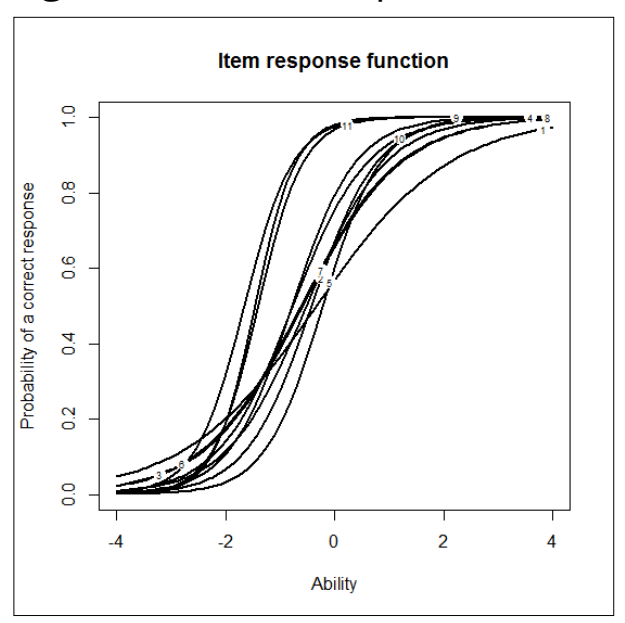

Figure 02 shows the ICC of each item, where it is possible to verify the position and the discrimination of each one. It is observed that several items are present within a range of $-1,7$ to $-0,2$, that is, they have a similar power of discrimination. The characteristic curves are mostly in the negative part of the scale, indicating that in general, items have a greater capacity to discriminate individuals with below average knowledge than individuals with above average ability. It should be emphasized that research has indicated a low level of Financial Knowledge of the population, that is, it is more common to find individuals with below average knowledge. Next, we tried to evaluate the information functions of the items and the instrument (Figure 03). 
Figure 3 - Item Information Function and Test Information Function of the Financial Knowledge Scale

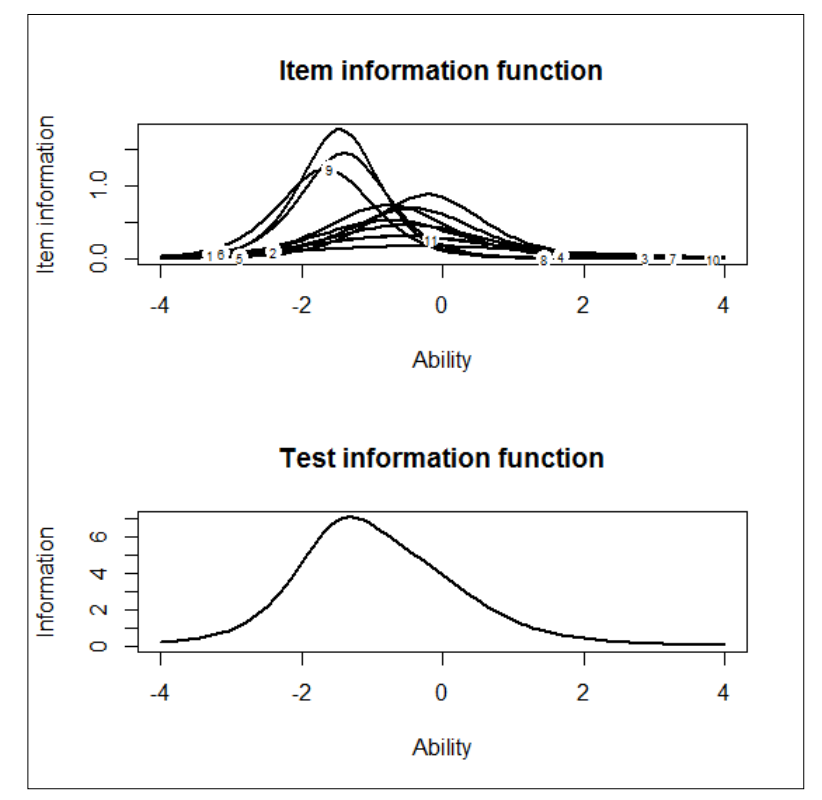

From Figure 03, it is identified that in the Total Information Curve obtained by the sum we have the information functions of all the items, the items with the highest information value are located in the interval where the abilities takes values between 2 and 1. Thus, it is verified that the instrument presents a higher level of information for the individuals like ability in this interval. Considering that the ability scale has mean zero and standard deviation a, the instrument presents a higher level of information for individuals with abilities between two standard deviations below and an aboveaverage deviation.

In the ICC image it is noticed that there is a great variation with respect to the position of the inflection point of each curve, which is directly related to the parameter $b_{i}$ of difficulty of each item, that is, the scale has items with different degrees of difficulty. It is also observed the existence of variations in the inclination that each curve presents, inclination that corresponds to the value that the parameter $a_{i}$ assumes, that is, parameter of discrimination.

After obtaining the parameters, the level of ability was estimated. The Irtoys Package offers three estimation methods: maximum likelihood, maximum a posteriori and expected a posteriori (EAP), which was chosen for this estimation. Table 03 presents the anchor levels, their respective ability limits, the percentage of interviewees 
and the anchor items. Figure 04 shows frequency distribution of the Financial Knowledge indicator.

Table 3 - Intervals, percentage of cases, anchor and quasi-anchor items of ability levels in Financial Knowledge

\begin{tabular}{lcccc}
\hline Ability level & Intervals & Frequency (\%) & Anchor & Quasi-anchor \\
\hline Very low & $\mathrm{P} \leq-1.5$ & 5.20 & - & - \\
Low & $-1.5<\mathrm{p} \leq-0.5$ & 21.89 & $6,10,11,13$ & 4,8 \\
Average & $-0.5<\mathrm{p} \leq 0.5$ & 41.12 & $3,9,12$ & - \\
High & $0.5<\mathrm{p} \leq 1.5$ & 31.79 & 7 & - \\
\hline
\end{tabular}

Figure 4 - Histogram of the ability in Financial Knowledge

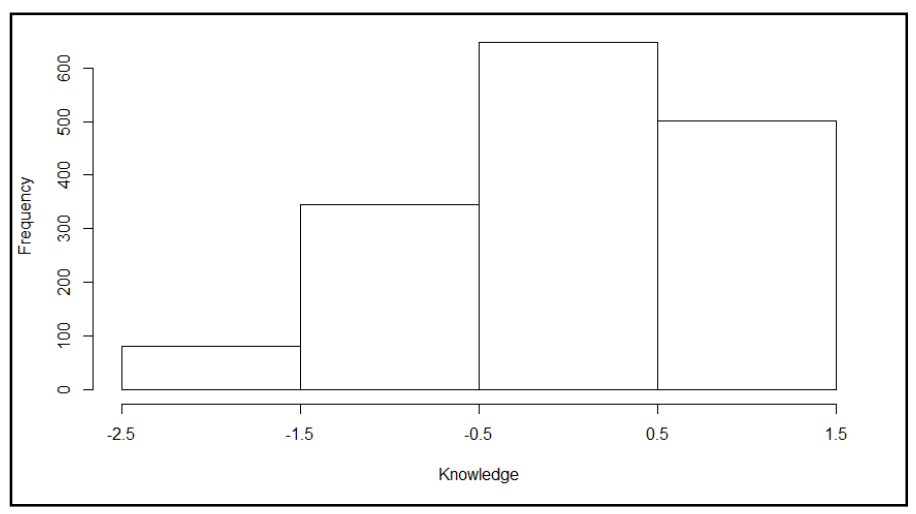

It can be seen from Table 03 that $41.12 \%$ of individuals have Financial Knowledge around zero, that is, they have an average proficiency. It is also seen that there are more individuals with proficiency above average than below average. Thus, the proficiency curve is slightly asymmetrical on the right. The left tail of the distribution is longer, since there is a small percentage of individuals with extremely low proficiency, while on the right no individuals with extremely high proficiency level is identified.

The low level of Financial Knowledge, with approximately 22\% of respondents, consists of anchor items $6,10,11$ and 13 and the quasi-anchor questions 4 and 8 . Individuals at this level are able to carry out simple financial operations, such as resources, make basic calculations with interest rates, understand the concept and impact of inflation on the cost of products and have a basic notion of risk. These topics are characteristics of what the literature has treated as Basic Financial Knowledge, that is, these individuals have the basic skills in financial education (GERRANS; HEANEY, 2014). 
The average level of Financial Knowledge, in addition to mastering low-level themes, advances in the ability to solve anchor questions 3, 9, and 12 In this group, individuals are seen to master more complex issues such as comparative analysis of interest, know the operation of basic financial products such as savings and are aware of the costs, risks and returns of financial products.

On the other hand, the high level, with $32 \%$ of respondents, has as an anchor question item 7, clearly indicating that the individuals that are part of this group are those capable of understand more complex concepts such as portfolio diversification. The understanding of the concept of diversification implies more elaborated Financial Knowledge, such as risk, return and correlation of a set of assets, being, therefore, a topic classified as more advanced in the studies of Financial Knowledge (POTRICH; VIEIRA; KIRCH, 2016, POTRICH; VIEIRA, 2018).

The next step was to analyze the Financial Attitude. This scale is composed of ten likert five-point questions and aims to identify how the individual evaluates their financial management. We first present the descriptive statistics of the items that make up the construct (Table 04).

Table 4 - Mean and percentage frequencies of the Financial Attitude scale

\begin{tabular}{|c|c|c|c|c|c|c|c|}
\hline Item & Variables & Mean & 1 & 2 & 3 & 4 & 5 \\
\hline 14 & It is important to set goals to the future. & 4.54 & 0.32 & 0.70 & 1.72 & 39.34 & 57.92 \\
\hline 15 & $\begin{array}{l}\text { I do not worry about the future, I live only in the } \\
\text { present. }\end{array}$ & 1.87 & 39.94 & 44.28 & 5.94 & 8.05 & 1.79 \\
\hline 16 & Saving is impossible for our family. & 2.21 & 25.81 & 49.03 & 7.03 & 14.84 & 3.29 \\
\hline 17 & $\begin{array}{l}\text { After deciding about money, I tend to worry too } \\
\text { much about my decision. }\end{array}$ & 3.37 & 4.75 & 17.00 & 22.90 & 47.53 & 7.83 \\
\hline 18 & $\begin{array}{l}\text { I like to buy thing because it makes me feel } \\
\text { good. }\end{array}$ & 3.21 & 7.54 & 20.94 & 23.90 & 38.60 & 9.02 \\
\hline 19 & It is hard to build a family spending plan. & 2.70 & 14.73 & 40.03 & 11.28 & 28.81 & 5.15 \\
\hline 20 & $\begin{array}{l}\text { I am willing to spend money on things that are } \\
\text { important to me. }\end{array}$ & 3.79 & 3.84 & 9.47 & 8.70 & 60.08 & 17.91 \\
\hline 21 & $\begin{array}{l}\text { I believe the way that I manage my money will } \\
\text { affect my future. }\end{array}$ & 3.74 & 4.80 & 15.86 & 9.02 & 41.43 & 28.90 \\
\hline 22 & $\begin{array}{l}\text { I think it is more satisfying to spend money than } \\
\text { save it for the future. }\end{array}$ & 2.20 & 23.01 & 48.26 & 16.20 & 10.35 & 2.19 \\
\hline 23 & Money is made to be spent. & 2.93 & 11.26 & 27.95 & 22.73 & 32.90 & 5.16 \\
\hline
\end{tabular}

When analyzing the Financial Attitude, it is observed that, on average, the participants presented adequate financial attitudes, considering that the scale varied 
from one (1) to five (5) points, in an ascending scale, where 1 is equivalent to financial attitudes and 5 corresponds to bad financial attitudes, except for questions 14 and 21 .

The best financial attitudes are related to the issues related to the financial future, highlighting the issues 14 and 21, which has inverted scales and therefore presents values that demonstrate a great Financial Attitude regarding the future concern, in which almost all the respondents (97.26\%) there is agreement or total agreement that it is important to set goals for the future and $70.33 \%$ that the way they are managing their money will affect their future.

In the same context, the questions 15 and 22 also demonstrate good financial attitudes by presenting the disagreement of the respondents on these issues. For $84.22 \%$ there is the disagreement that they do not care about the future and live only the present and $71.27 \%$ do not consider it more satisfactory to spend money than to save for the future.

However, when it comes to decision-making attitudes, they are unsatisfactory. Highlighting the question 20 in which $77.99 \%$ of individuals agree to be willing to spend money on important things, and the question 17 that for more than half of the respondents (55.36\%) there is concern after the decisions made about money.

Clearly, it is verified that the respondents in general have negative attitudes towards the decision making. On the other hand, they have positive attitudes about their future concern regarding goal setting and financial management of their present so that it does not have a negative impact on the future.

Then, the factor analysis was performed. Figure 05 presents the Screeplot.

Figure 5 - Screeplot of the Financial Attitude

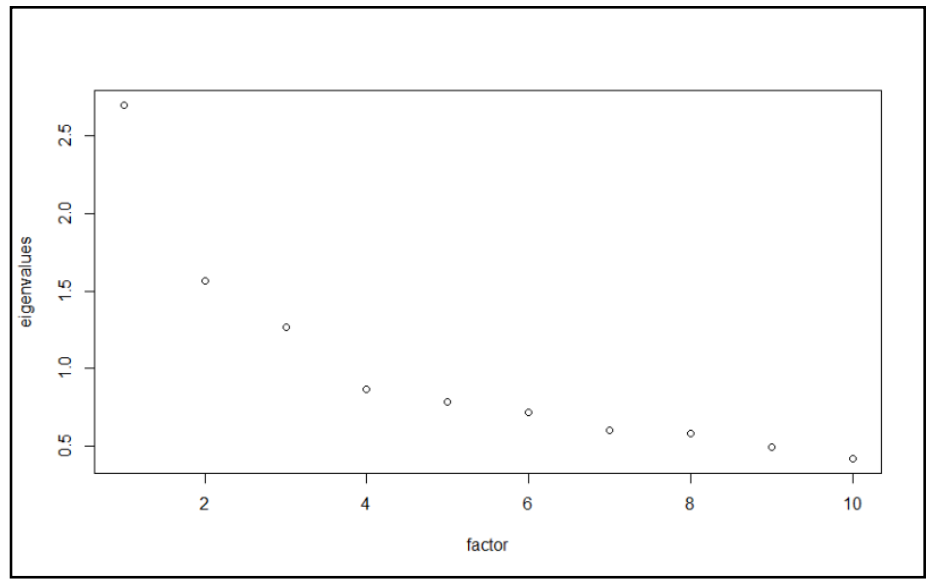


Then, the factorial analysis showed that the first factor represents $26.79 \%$ of the explained variance, indicating that there is a dominant factor, according to Reckase (1979), which justifies the application of a model one-dimensional, as is the case with GRM. Thus, we started the estimation of the GRM as defined in equation 2. The scale initially counted with ten items, however, items 20,17, 21 and 18 were excluded because they presented, respectively, discrimination values $(0.129,0.292,0.212,0.636)$ all considered low according to the criterion of Baker (2001). Table 05 presents the estimated parameters.

Table 5 - Coefficients and standard errors of the parameters of difficulty and discrimination of the Financial Attitude scale

\begin{tabular}{ccccccc}
\hline Item & $\mathrm{a}_{\mathrm{i}}$ & $\mathrm{b}_{\mathrm{i} 0}$ & $\mathrm{~b}_{\mathrm{il}}$ & $\mathrm{b}_{\mathrm{i} 2}$ & $\mathrm{~b}_{\mathrm{i3}}$ & $\mathrm{b}_{\mathrm{ik}}$ mean \\
\hline 14 & 0.951 & -6.308 & -5.195 & -4.157 & -0.397 & -4.014 \\
15 & 1.748 & -3.069 & -1.832 & -1.407 & 0.351 & -1.489 \\
16 & 1.120 & -3.515 & -1.663 & -1.217 & 1.152 & -1.311 \\
19 & 0.971 & -3.406 & -0.843 & -0.274 & 2.081 & -0.611 \\
22 & 1.750 & -2.927 & -1.605 & -0.768 & 1.026 & -1.069 \\
23 & 0.971 & -3.380 & -0.600 & 0.512 & 2.445 & -0.256 \\
\hline
\end{tabular}

In Table 05, the estimates of the parameters of the items ( $a_{i}$ and $\left.b_{i, k}\right)$ for each category $\left(b_{i, 1}, b_{i, 2}, b_{i, 3}\right.$ and $\left.b_{i, 4}\right)$ are obtained by the LTM package. All items had a mean negative difficulty parameter, and the three items with the highest value of $b_{i}$, average $\mathrm{k}$ were, in ascending order, items $22,19,23$. in ascending order, were items 14,15 and 16. The discrimination parameters were between 0.951 and 1.750 indicating a good discrimination capacity of the scale items. Figure 06 shows the Information Curves for each item and the Test. 
Figure 6 - Item Information Curves and Test Information Function of the Financial Attitude item

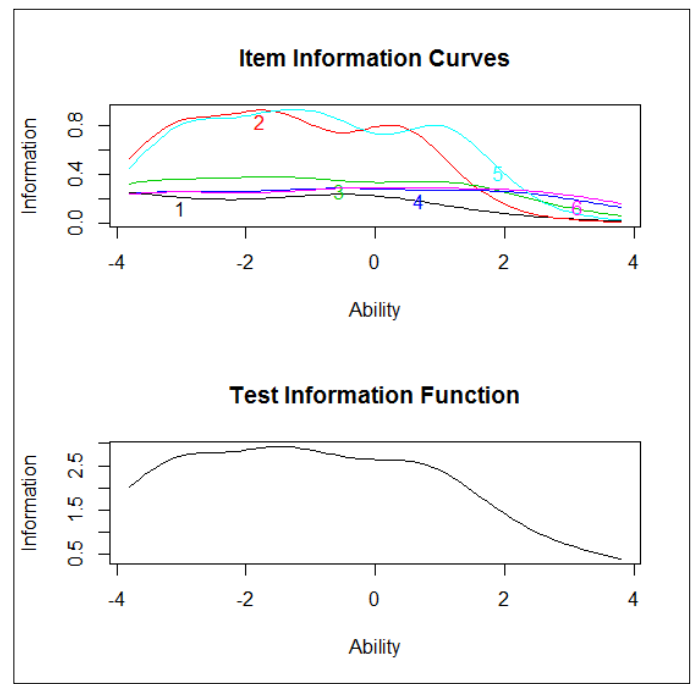

Note: item " 1 " represents item " 14 " in table 5 and so on: $2=15,3=16,4=19,5=22$ and $6=23$.

It is observed that items 15 (second item in the scale) and 22 (fifth item in the scale) are the ones that most contribute to the information of the Attitude scale. In addition, the measuring instrument has more information in the range of -4 to 2 . This means that it is more suitable to measure satisfaction of individuals who have attitude in this range. Considering that the attitude scale is constructed with mean zero and standard deviation 1, the instrument has the highest informational level for individuals in a range of minus 4 deviations below the mean up to two more deviations above the mean, that is, the scale is adequate for the vast majority of individuals.

Next, the ability level was estimated and the anchor and quasi-anchor categories were identified. Table 06 presents the ability intervals in Financial Attitude and the respective anchor and quasi-anchor categories. Figure 07 shows the frequency distribution of the estimated ability.

Table 6 - Intervals, anchor and quasi-anchor items of ability levels in Financial Attitude

\begin{tabular}{|c|c|c|c|c|c|}
\hline \multirow[t]{2}{*}{ Ability Level } & \multirow[t]{2}{*}{ Intervals } & \multicolumn{4}{|c|}{ Anchor and Quasi-Ânchor (*) Items } \\
\hline & & b0-Agree & b1-Indiferent & b2-Disagree & b3-Strongly Disagree \\
\hline Very Low & $p \leq-1.5$ & $15^{*}, 22$ & - & - & - \\
\hline Low & $-1.5<p \leq-0.5$ & - & $15,22,16$ & 15 & - \\
\hline Average & $-0.5<p \leq 0.5$ & - & - & $22,16^{*}$ & - \\
\hline High & $0.5<p \leq 1.5$ & - & - & - & 15 \\
\hline Very High & $p>1.5$ & - & - & - & $22,16^{*}, 19 *$ \\
\hline
\end{tabular}


Figure 7 - Frequency distribution for the ability in Financial Attitude

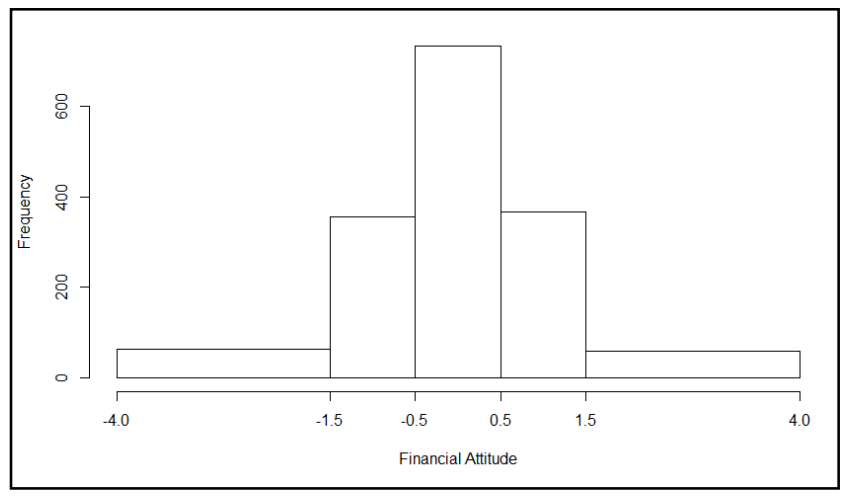

The very low ability level is characterized by individuals who do not care about the future, live the present, and find it more satisfying to spend money than to save for the future. At the low level, respondents are indifferent to these issues and also to the possibility of the family saving. On the other hand, at the high level of ability in Financial Attitude there is a concern for the future and not too high, in addition to the concern there is a total disagreement with the idea that saving is not important and that planning the expenses is difficult, that is, individuals more skilled in Financial Attitude tend to think in the future, understand the importance of saving and controlling expenses. The distribution (Figure 07) shows the slightly left tail is longer. Most of the respondents presented ability in Financial Attitude around the mean and there were a few cases of individuals with much lower-than-average ability ( -3 and -4$)$.

Finally, we analyze the Financial Behavior scale. The scale consisted of twentyseven likert five-point questions. The lower the respondent's frequency in the statements made, the worse his behavior in managing his finances. It is also worth noting that questions 34,35 and 48 that portray negative financial behaviors were interpreted in an inverted way, that is, the lower the value found in the scale, the better the individual's financial behavior in these matters. The descriptive statistics of the items are presented in Table 07. 
Table 7 - Percentage averages and frequencies of the Financial Behavior scale

\begin{tabular}{|c|c|c|c|c|c|c|c|}
\hline Item & Variables & Mean & 1 & 2 & 3 & 4 & 5 \\
\hline 24 & $\begin{array}{l}\text { I make notes and control my personal } \\
\text { spending (e. g. monthly spreadsheet of } \\
\text { income and expenses. }\end{array}$ & 3.11 & 16.40 & 17.20 & 26.10 & 19.40 & 20.80 \\
\hline 25 & I compare prices when making a purchase. & 4.00 & 2.00 & 4.70 & 21.60 & 35.20 & 66.60 \\
\hline 26 & $\begin{array}{l}\text { I save some money I receive each month for a } \\
\text { future need. }\end{array}$ & 3.43 & 9.10 & 13.00 & 28.80 & 24.10 & 25.00 \\
\hline 27 & I have a spending/budget plan & 3.22 & 12.00 & 17.10 & 26.90 & 24.10 & 19.80 \\
\hline 28 & $\begin{array}{l}\text { I am able to identify the costs I pay to buy a } \\
\text { product on credit. }\end{array}$ & 3.76 & 7.20 & 7.60 & 22.10 & 27.90 & 35.30 \\
\hline 29 & I set goals to guide my financial decisions. & 3.64 & 4.70 & 9.60 & 26.70 & 35.30 & 23.70 \\
\hline 30 & $\begin{array}{l}\text { I usually reach the goals I set when managing } \\
\text { my money. }\end{array}$ & 3.71 & 1.70 & 4.90 & 31.10 & 45.80 & 16.60 \\
\hline 31 & $\begin{array}{l}\text { I discuss with my family about how I spend our } \\
\text { money. }\end{array}$ & 3.30 & 12.60 & 14.10 & 27.10 & 23.40 & 22.80 \\
\hline 32 & I pay my bills on time. & 4.52 & 0.60 & 1.40 & 8.00 & 25.40 & 64.50 \\
\hline 33 & I save a part of my income every month. & 3.34 & 10.30 & 15.50 & 27.90 & 22.50 & 23.80 \\
\hline 34 & I spend my money before getting it. & 1.98 & 41.90 & 27.00 & 24.40 & 5.20 & 1.60 \\
\hline 35 & $\begin{array}{l}\text { I often ask family or friends to borrow me } \\
\text { money to pay my bills. }\end{array}$ & 1.75 & 51.40 & 29.50 & 13.60 & 3.60 & 1.90 \\
\hline 36 & $\begin{array}{l}\text { I analyze my bills before making a large } \\
\text { purchase. }\end{array}$ & 4.46 & 1.40 & 2.60 & 8.70 & 22.70 & 64.60 \\
\hline 37 & $\begin{array}{l}\text { Every month I have enough money to pay all } \\
\text { expenses of my own and fixed household } \\
\text { expenses. }\end{array}$ & 4.24 & 1.90 & 4.00 & 11.60 & 33.10 & 49.50 \\
\hline 38 & $\begin{array}{l}\text { I keep organized financial records and I can } \\
\text { find documents easily. }\end{array}$ & 3.56 & 7.80 & 12.00 & 23.70 & 29.90 & 26.60 \\
\hline 39 & $\begin{array}{l}\text { I avoid buying on impulse and use shopping as } \\
\text { form of entertainment. }\end{array}$ & 3.71 & 7.10 & 7.90 & 22.30 & 32.30 & 30.40 \\
\hline 40 & $\begin{array}{l}\text { I pay the credit card invoices in full to avoid } \\
\text { interest charges. }\end{array}$ & 4.43 & 3.30 & 2.20 & 11.00 & 15.40 & 68.10 \\
\hline 41 & $\begin{array}{l}\text { I save my money regularly to achieve long- } \\
\text { term financial goals such as, e. g. my children's } \\
\text { education, purchasing a home, retirement. }\end{array}$ & 3.14 & 17.90 & 16.30 & 22.40 & 20.70 & 22.60 \\
\hline 42 & I know the percentage I pay as income tax. & 2.93 & 29.40 & 13.50 & 17.10 & 14.60 & 25.50 \\
\hline 43 & $\begin{array}{l}\text { I have my money invested in more than one } \\
\text { kind of investment (real sate, stocks, savings). }\end{array}$ & 2.41 & 41.20 & 16.80 & 15.70 & 12.20 & 14.00 \\
\hline 44 & I start saving more when I get pay raise. & 3.13 & 14.90 & 15.10 & 30.60 & 21.50 & 18.00 \\
\hline 45 & $\begin{array}{l}\text { I have a financial reserve equal to or greater } \\
\text { than } 3 \text { time my monthly expenses, and it can } \\
\text { be quickly accessed. }\end{array}$ & 2.58 & 35.20 & 19.90 & 16.20 & 11.90 & 16.80 \\
\hline 46 & Calculate my equity annually. & 2.49 & 38.10 & 16.90 & 17.80 & 12.20 & 15.10 \\
\hline 47 & $\begin{array}{l}\text { Before buying anything, I carefully check } \\
\text { whether I am able to pay for it. }\end{array}$ & 4.40 & 2.30 & 2.60 & 10.20 & 23.00 & 61.90 \\
\hline 48 & $\begin{array}{l}\text { People think my income is not enough to } \\
\text { cover my expenses. }\end{array}$ & 2.12 & 42.50 & 21.30 & 23.40 & 7.40 & 5.40 \\
\hline 49 & $\begin{array}{l}\text { In the last } 12 \text { months I have been able to save } \\
\text { money. }\end{array}$ & 3.23 & 15.70 & 13.90 & 25.20 & 22.10 & 23.10 \\
\hline 50 & $\begin{array}{l}\text { When deciding on which financial products } \\
\text { and loans I will use, I consider the options } \\
\text { form various companies/banks. }\end{array}$ & 3.65 & 13.00 & 5.80 & 20.70 & 24.00 & 36.50 \\
\hline
\end{tabular}


It can be observed that the Financial Behavior of respondents, on average, was adequate, considering that in the ascending scale, 1 is equivalent to bad financial behavior and 5 corresponds to good financial behavior. The best Financial Behaviors refer mainly to the payment without delay of accounts, the definition of objectives and the accomplishment of a previous analysis of the purchases. Regarding the payment of bills, the issue is highlighted 32 which $89.90 \%$ of respondents say they always or almost always pay their bills on time; the question "40, by presenting a significant portion (68.10\%) that indicated the option that always pays your credit card bills and the question 37 , pointing out that $82.60 \%$ always or almost always have enough money every month to cover their bills and only $1.90 \%$ say they never own.

In this context the questions 35 and 48 also demonstrate good financial behavior regarding the payment of bills without delay, since such issues have reversed scales and for $80.90 \%$ of individuals never or almost never you need to borrow money to pay off your bills and $63.80 \%$ say that people never or hardly ever find that their income is not enough for this. Regarding the analysis of the questions related to the definition of objectives, the questions 29 and 30 by presenting averages that refer to good financial behavior, mainly because $62.40 \%$ of the respondents indicate that they always or almost always reach the determined goals and more than half (59\%) affirm set goals to get financially oriented.

Regarding the performance of a prior analysis of purchases, the questions 36 and 47 evidence that individuals present positive behaviors, because for more than $84 \%$ of respondents always or almost always these two situations occur in advance. In addition, $71.80 \%$ always or almost always compare prices when making a purchase and $63.20 \%$ can identify the costs they pay when buying a product in credit. These questions show that individuals are worried about analyzing their financial conditions prior to the purchase, thus avoiding indebtedness.

Moreover, the data indicate that $68.90 \%$ of the respondents say that they never or hardly ever spend the money before obtaining it and only $1.60 \%$ always do, in addition to $62.70 \%$ avoid, always or almost always, buy impulse and use purchases as a way of fun, finding out that individuals have a low propensity to buy impulsively. 
However, when analyzing the issues of savings and the economies that individuals realize, bad financial behaviors are perceived. Particularly in questions 45 and 43 where $55.10 \%$ of the respondents say they never or almost never have a financial reserve of at least three times the value of their expenses and only $14 \%$ say they always have their money invested in more than one type of investment.

Another worrying factor in this context is that $30.60 \%$ of individuals sometimes save more when they receive a salary increase and only $23.80 \%$ always keep part of their monthly income. In addition, the question 46 also shows values that indicate poor financial behavior, where $55 \%$ of individuals say they never or almost never do.

In general, the respondents present good financial behavior on issues such as payment of bills without delay, setting objectives and prior analysis of purchases, but they have issues to be improved, such as saving a portion of their rents and with this to guard against some unforeseen event that may occur in the future, having a financial reserve for this purpose. The factor analysis of this factor presented the following screeplot (Figure 08).

Figure 8 - Screeplot of Financial Behavior

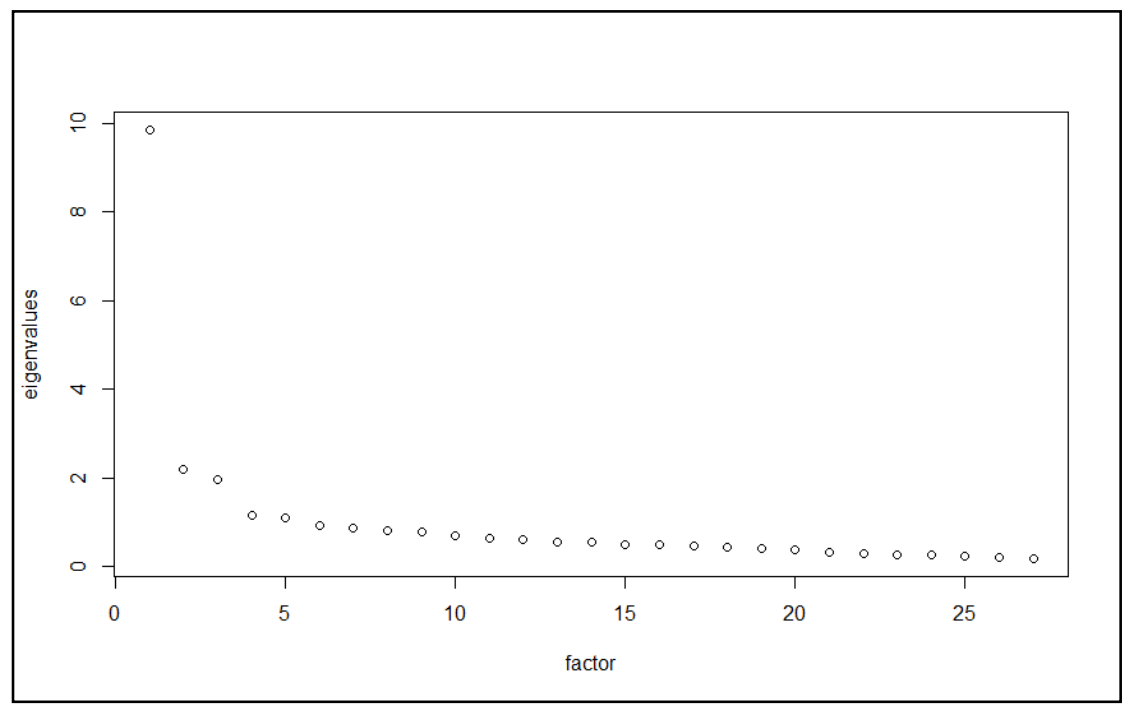

The factorial analysis for categorical data indicated that the first factor represents $37.48 \%$ of the explained variance. After the first estimation of the GRM, items 48 and 31 were withdrawn because they presented low discrimination parameters (respectively, 0.404 and 0.412 ). Table 08 presents the coefficients estimated according to equation 03. 
Table 8 - Coefficients and standard errors of the parameters of difficulty and discrimination for Financial Behavior

\begin{tabular}{lllllll}
\hline Item & $\mathrm{a}_{\mathrm{i}}$ & $\mathrm{b}_{\mathrm{i} 0}$ & $\mathrm{~b}_{\mathrm{il}}$ & $\mathrm{b}_{\mathrm{i} 2}$ & $\mathrm{~b}_{\mathrm{i} 3}$ & $\mathrm{~b}_{\mathrm{ik}}$ mean \\
\hline 24 & 0.881 & $-2,102$ & -0.902 & 0.510 & 1.750 & -0.186 \\
25 & 0.833 & -4.993 & -3.454 & -1.223 & 0.800 & -0.405 \\
26 & 2.295 & -1.626 & -0.916 & 0.053 & 0.870 & -0.405 \\
27 & 1.487 & -1.769 & -0.802 & 0.236 & 1.311 & -0.256 \\
28 & 1.043 & -2.830 & -1.963 & -0.586 & 0.745 & -1.159 \\
29 & 1.739 & -2.361 & -1.452 & -0.276 & 1.032 & -0.764 \\
30 & 1.685 & -3.203 & -2.107 & -0.393 & 1.434 & -1.067 \\
32 & 1,329 & -4.417 & -3.446 & -2.058 & -0.573 & -2.624 \\
33 & 2.271 & -1.554 & -0.787 & 0.136 & 0.926 & -0.320 \\
34 & 0.964 & -4.072 & -3.117 & -0.970 & 0.418 & -2.093 \\
35 & 0.827 & -5.137 & -3.769 & -1.942 & -0.044 & -2.723 \\
36 & 1.278 & -3.829 & -2.997 & -1.872 & -0.587 & -2.321 \\
37 & 1.279 & -3.630 & -2.637 & -1.506 & 0.044 & -1.932 \\
38 & 0.989 & -2.827 & -1.612 & -0.255 & 1.278 & -0.854 \\
39 & 0.726 & -3.831 & -2.616 & -0.773 & 1.300 & -1.480 \\
40 & 0.885 & -4.156 & -3.545 & -2.069 & -0.970 & -2.685 \\
41 & 2.125 & -1.172 & -0.5536 & 0.214 & 0.994 & -0.125 \\
42 & 1.035 & -1.009 & -0.326 & 0.480 & 1.266 & 0.103 \\
43 & 1.185 & -0.379 & 0.330 & 1.095 & 1.924 & 0.743 \\
44 & 1.648 & -1.474 & -0.711 & 0.406 & 1.350 & -0.107 \\
45 & 1.784 & -0.516 & 0.167 & 0.791 & 1.380 & 0.456 \\
46 & 1.318 & -0.491 & 0.181 & 0.976 & 1.722 & 0.597 \\
47 & 1.285 & -3.446 & -2.785 & -1.673 & -0.468 & -2.093 \\
49 & 2.139 & -1.257 & -0.657 & 0.169 & 0.969 & -0.194 \\
50 & 0.928 & -2.318 & -1.791 & -0.521 & 0.722 & -0.977 \\
\hline & & & & & &
\end{tabular}

The parameters $a_{i}$ were between 0.726 and 2.295 indicating good ability to discriminate the items of the knowledge scale. Those of medium difficulty presented both negative and positive values, indicating that the scale presents both easy items and more difficult items.

After, we tried to evaluate the information curves (Figure 09). 
Figure 9 - Item Information Curves and Test Information Function of the Financial Behavior

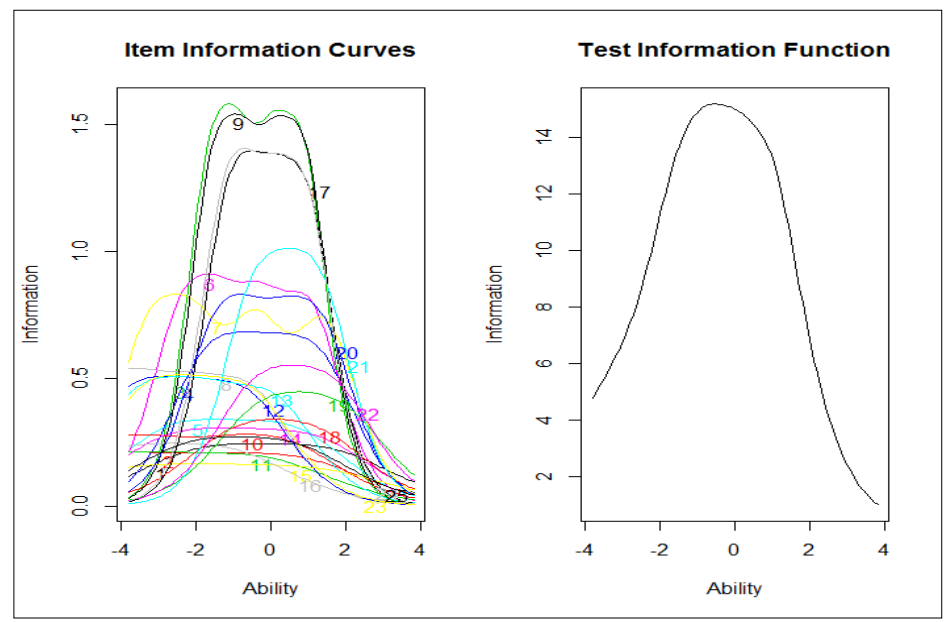

Note: item "1" represents item " 24 " in table 9 and so on: $2=25,3=26$ to $25=50$.

The items with the highest level of information were items 26, 33, 49 and 41 . Many items present information curves with shorter kurtosis, indicating that they are less informative for scale construction. Compared to the Financial Knowledge, the Financial Behavior Scale presented a much more symmetric Test Information Function, but the level of information for individuals below average is slightly higher than those above average. In the sequence, the level of ability was estimated and the categories anchors and almost anchors were identified. Table 09 presents the ability ranges and respective anchor and quasi-anchor categories. Figure 10 shows the frequency distribution of the estimated ability.

Table 9 - Intervals, anchor and quasi-anchor items of ability levels in Financial Behavior

\begin{tabular}{|c|c|c|c|c|c|}
\hline \multirow{2}{*}{$\begin{array}{l}\text { Ability } \\
\text { Level }\end{array}$} & \multirow[t]{2}{*}{ Intervals } & \multicolumn{4}{|c|}{ Anchor and Quasi-Ânchor (*) Items } \\
\hline & & b0 Almost Never & b1 Sometimes & $\begin{array}{l}\text { b2 Almost } \\
\text { Always }\end{array}$ & b3 Always \\
\hline Very Low & $p \leq-1.5$ & $29,30,28^{*}, 38^{*}$ & - & - & - \\
\hline Low & $\begin{array}{c}-1.5<\mathrm{p} \leq- \\
0.5\end{array}$ & $26,27,33,44$ & - & $37,32 *, 35^{\star}, 36 *$ & - \\
\hline Average & $-0.5<p \leq 0.5$ & $46,47,41 *, 42 *$ & $\begin{array}{c}26,27,33,42 \\
44,49,24^{\star}\end{array}$ & $30,28 *, 34 *, 39 *$ & $32,36,47,40 *$ \\
\hline High & $0.5<p \leq 1.5$ & - & $43^{*}, 45^{*}, 46^{*}$ & $\begin{array}{c}26,27,33,41,44 \\
49\end{array}$ & $37 *$ \\
\hline Very High & $p>1.5$ & - & - & $43^{*}$ & $\begin{array}{c}27,29,30,41 \\
42,44,33^{*} \\
38 *, 49 *\end{array}$ \\
\hline
\end{tabular}


Figure 10 - Frequency distribution for the ability in Financial Behavior

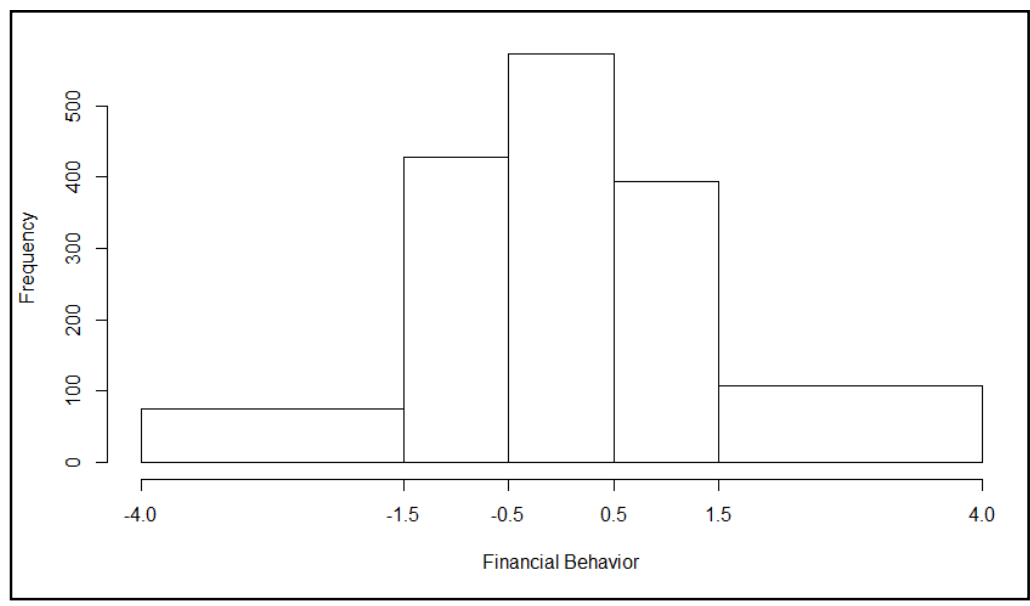

Table 09 shows that the very low level is characterized by being individuals who do not keep financial records of their finances, do not set goals to guide their financial decisions, and consequently also do not meet the financial objectives and cannot identify the costs of purchases in the credit. At the low level they almost never make reservations for future needs or have a spending plan. At the average ability level, sometimes they can perform these activities. Also, sometimes they can save when they receive increase, they know the rate that they pay of tax and they record and control the expenses. High ability level differs from middle level especially by how often they can perform activities. While at the middle level the activities are sometimes carried out, at the high level the same activities are almost always carried out.

The very high level, however, differs from the high level both by performing the same activities at a higher frequency (always) and by performing other activities such as charting financial goals, maintaining a savings, analyzing your finances before making a large purchase and keeping records financial statements. The frequency distribution (Figure 10) shows some small deviations of asymmetry and kurtosis. Overall, the majority of respondents presented the ability around the mean. Just as in Financial Attitude ability, some individuals had Financial Knowledge well below average (-3 or lower). 


\section{CONCLUSIONS}

Financial literacy is one of the pillars of financial citizenship and an instrument capable of directly influencing important behavioral factors, such as compulsive shopping, proper use of credit cards, and propensity for indebtedness. As the OECD itself (2015) argues, financial literacy is an indispensable way for individuals to achieve financial well-being. This is corroborated by Messy and Monticone (2016) in stating that financial literacy is essential for the protection and financial inclusion of consumers.

In this context, several countries, including Brazil, are seeking to implement national strategies to improve the level of financial literacy of the population. Some initial actions such as the incorporation of financial education into the curricular base and the creation of the National Financial Education Strategy (NFES) are already being implemented. However, a literature review of consolidated financial literacy has not yet been found in the literature.

Thus, in order to answer the question: How to properly measure the financial literacy level of individuals?, this work developed and validated through the Item Response Theory (IRT) an instrument for the evaluation of Financial Literacy. The results for the Financial Knowledge construct have demonstrated that the lowest levels in the scale dominate only the basic knowledge of finance, and as you move up the scale individuals in addition to mastering the basic knowledge begin to master items that represent more advanced knowledge.

The results of the estimation of the GRM for Financial Attitude indicated that one can reduce the initial ten items to six items. With the six items we obtained a ability scale with a relatively symmetric informational level around zero. As all items have presented negative discrimination, it is possible in future researches to think about the creation of questions with higher level of exigency for this construct. For the behavior model, only two issues were excluded. The informational level of the construct can also be considered adequate.

Overall, the results pointed to the adequacy of the proposed instrument to evaluate the three constructs that form the financial literacy. It is understood, therefore, that the instrument can be used for the purpose of evaluating the knowledge, the 
attitude and the financial behavior of the individuals. The financial literacy indicator proposed here can be useful both to assess the initial level of knowledge, in order to identify the main themes to be addressed in financial education courses, and to compare different socio-demographic groups, seeking to identify the priority groups of care in the strategies. Also, it can be used, in longitudinal studies, to identify the effects of adopting financial education strategies on individuals' financial ability.

In fact, in order to allow a multidimensional analysis of the effects of the strategies adopted by the various countries to improve levels of financial literacy in the future, it is essential that among the various dimensions of analysis, a dimension related to the financial literacy indicator may be one of the parameters.

Financial literacy has become an essential component of successful adulthood. However, its multidimensionality and the associations between its three dimensions are a challenge for educational systems. Since beyond financial knowledge, efforts and techniques are needed to stimulate attitude and behavior change, as knowing finance will not be helpful if, at the time of making financial decisions, individuals do not have appropriate financial behaviors. Therefore, improving financial literacy will result in citizens who are more aware of their consumption decisions, less prone to delinquency, and more capable of achieving adequate family financial management. Including financial literacy in the global political agenda can play an important role in the financial empowerment of citizens and, as a consequence, have a positive influence on the stability of financial and economic systems (BCB, 2017). 


\section{REFERENCES}

ATKINSON, A., MESSY, F. Measuring financial literacy: results of the OECD / International Network on Financial Education (INFE) pilot study, OECD Publishing.2012, http://dx.doi.org/10.1787/5k9csfs90fr4-en.

BANCO CENTRAL DO BRASIL-BCB Série cidadania financeira: estudos sobre educação, proteção e inclusão, $5^{a}$ Ed. Brasília: Banco Central do Brasil http://www.bcb.gov.br/nor/relincfin/serie_cidadania_financeira_pesquisa_ infe_br_\%200443_2017.pdf. 2017, Acessed 06 jun. 2018.

BAKER, F. B. The basics of item response theory. 2001, http://files.eric.ed.gov/fulltext/ED458219.pdf. Acessed 15 jun. 2016.

BEATON, A. E., ALLEN, N. L. Interpreting scales through scale anchoring. Journal of Educational Statistics. 1992, 17, 191-204.

BIRNBAUM, A. Some Latent Trait Models and Their Use in Infering an Examinee's Ability. In: Lord, F. M., Novick, M. R. Statistical Theories of Mental Test Scores. Reading, MA: Addison-Wesley. 1968.

BUCHER-KOENEN, T., LUSARDI, A., ALESSIE, R., VAN ROOIJ, M. How Financially Literate Are Women? An Overview and New Insights. Journal of Consumer Affairs. 2016, 51, 255-283.

CHEN, H., VOLPE, R. P. An analysis of personal financial literacy among college students. Financial Services Review, 1998, 7 (2), 107-128.

CLARK, R., LUSARDI, A., MITCHELL, O. S Employee Financial Literacy and Retirement Plan Behavior: A Case Study. NBER Working Paper n. 21461.2015, http://www.nber.org/papers/w21461. Acessed 21 feb 2016.

EMBRETSON, S. , REISE, S. P. Item Response Theory for Psychologists. New Jersey: Lawrence Erlbaum Associates, Inc. Publishers 2000.

FAZIO, R. H., EISER, J. R., SHOOK, N. J. Attitude formation through exploration: Valence asymmetries. Journal of Personality and Social Psychology. 2004, 87, 293-311.

JUNIOR, Fernando de Jesus Moreira. Contribuições da Teoria da Resposta ao Item nas Avaliações Educacionais. Ciência e Natura, v. 36, p. 58-72, 2014.

LORENZO-SEVA, U., FERRANDO, P. J. Program FACTOR at 10: Origins, development and future directions. Psicothema, 2017, 29(2), 236-240. 
GERRANS, P. \& HEANEY, R. The Role of Undergraduate Personal Finance Education in Financial Literacy, Financial Attitudes and Financial Behaviours. Social Sciense Research Network. 2014, http://dx.doi.org/10.2139/ssrn.25373. Acessed 29 feb. 2016.

KADOYA, Y., KHAN, M.S.R. What determines financial literacy in Japan? Journal of Pension Economics \& Finance, 2019, 1-19.

KLAPPER, L., LUSARDI, A., PANOS, G. A. Financial literacy and its consequences: Evidence from Russia during the financial crisis. Journal of Banking \& Finance. 2013, 37(10), 3904-3923 https://doi.org/10.1016/j.jbankfin.2013.07.014.

KNOLL, M. A. Z., HOUTS, C. R. The financial knowledge scale: an application of item response theory to the assessment of financial literacy. The Journal of Consumer Affairs. 2012, 46(3), 381-410 (2012) https://doi.org/10.1111/j.1745-6606.2012.01241.x.

LUSARDI, A., MITCHELL, O. S. Financial literacy and retirement planning in the United States. Journal of Pension Economics and Finance. 2011, 10(4), 509-525.

LUSARDI, A., MITCHELL, O. S. The Economic Importance of Financial Literacy: Theory and Evidence. Journal of Economic Literature, 2014, 52(1), 5-44.

LUSARDI, A., OGGERO N., YAKOBOSKI P. J. The TIAA Institute-GFLEC Personal Finance Index: A New Measure of Financial Literacy. Global Financial Literacy Excellence Center (GFLEC), 2017. Disponível em: http://gflec.org/wpcontent/uploads/2017/04/TIAA_GFLEC_Report_PFinIndex_final2.pdf?x87657. Acesso em: 18 jul.. 2019.

MESSY, F., MONTICONE, C. Financial Education Policies in Asia and the Pacific. OECD Working Papers on Finance, Insurance and Private Pensions, OECD Publishing, Paris, 2016, n. 40. http://dx.doi.org/10.1787/5jm5b32v5vvc-en Acessed 23 Feb. 2016.

NATIONAL FINANCIAL CAPABILITY STUDY (NFCS) Financial Capability in the United States - Report of Findings from the 2012 National Financial Capability Study.2013, Financial Industry Regulatory Authority (FINRA) Investor Education Foundation.

O'NEILL, B., XIAO, J. Financial Behaviors Before and After the Financial Crisis: Evidence from an Online Survey. Journal of Financial Counseling and Planning. 2012, 23(1), 3346.

OPLETALOVÁ, A. (2015) Financial education and financial literacy in the Czech education system. Procedia - Social and Behavioral Sciences. 171(16), 1176-1184.

ORGANISATION FOR ECONOMIC CO-OPERATION AND DEVELOPMENT (OECD). : Women and Financial Education: Evidence, Policy Responses and Guidance, OECD Publishing., 2013, http://dx.doi.org/10.1787/9 789264202733-en. Acessed 25 may. 2018. 
: 2015 OECD/INFE Toolkit for Measuring Financial Literacy and Financial Inclusion. OECD Publishing. 2015, http://www.oecd.org/daf/fin/financialeducation/2015_OECD_INFE_Toolkit_Measuri ng_Financial_Literacy.pdf. Acessed 24 Feb 2016.

PISA 2015 Results in Focus. OECD Publishing. 2018, http://www.oecd.org/pisa/pisa-2015-results-in-focus.pdf. Acessed 30 May 2018.

: 2017 (OECD). G20/OECD INFE report on adult financial literacy in G20 countries. [s.l: s.n.]. 2017, Disponível em: http://www.oecd.org/daf/fin/financialeducation/G20-OECD-INFE-report-adult-financial-literacy-in-G20-countries.pdf. Acessed 16 mar 2019.

PARTCHEV, I. Package irtoys: Simple interface to the estimation and plotting of IRT models. CRAN. $\quad \mathbf{R} \quad$ Project $2016 . \quad$ http://cran.rproject.org/web/packages/irtoys/irtoys.pdf Acessed 24 May. 2017.

PIETRAS, G. Uma abordagem sobre matemática financeira e educação financeira no ensino médio. 2014, 104 f. Dissertação (Mestre em Matemática), Universidade Estadual de Ponta Grossa.

POTRICH, A. C. P., VIEIRA, K. M., KIRCH, G. Determinants of Financial Literacy: Analysis of the Influence of Socioeconomic and Demographic Variables. Revista Contabilidade \& Finanças. 2015, 26(69), 362-377. http://dx.doi.org/10.1590/1808-057x201501040.

POTRICH, A. C. G. VIEIRA, K. M., CORONEL, D. A., Bender Filho, R.. Financial literacy in Southern Brazil: Modeling and invariance between genders. Journal of Behavioral and Experimental Finance, v. 6, p. 1-12, 2015a.

POTRICH, A. C. G., VIEIRA, K. M., MENDES-DA-SILVA, W. Development of a financial literacy model for university students. Management Research Review, v. 39, n. 3, p. 356-376, 2016a.

POTRICH, A. C. P., VIEIRA, K. M., KIRCH, G. Are you Financially Literate? Discover in the Financial Literacy BASE - Revista de Administração e Contabilidade da Unisinos. 2016, 13(2), 153-170. http://dx.doi.org/10.4013/base.2016.132.05.

POTRICH, A.C.G., VIEIRA, K.M., KIRCH, G. How well do women do when it comes to financial literacy? Proposition of an indicator and analysis of gender differences. Journal Behavioral and Experimental. Finance. 2018, 17, 28-41 https://doi.org/10.1016/J.JBEF.2017.12.005.

QFINANCE. Definition of attitude. QFinance - The Ultimate Financial Resource. 2013, http://www.qfinance.com/dictionary/attitude. Acessed 15 Sep 2015. 
R CORE TEAM. R: A language and environment for statistical computing. R Foundation for Statistical Computing, 2017, Vienna, Austria. https://www.R-project.org/. Acessed 24 May 2018.

RECKASE, M. D. Unifactor latent trait models applied to multifactor tests: Results and implications. Journal of Educational Statistics. 1979, 4, 207-230.

RIZOPOULOS, D. Itm: An $\mathbf{r}$ packages for latent variable modelling and item response theory analyses. $\mathrm{R}$ package. 2015, https://cran.rproject.org/web/packages/ltm/ltm.pdf Acessed 24 May 2018.

SAMEJIMA, F. A. Estimation of latent ability using a response pattern of graded scores. Psychometric 1969, Monograph. 17.

SCHMEISER, M. D., SELIGMAN, J. S.: Using the Right Yardstick: Assessing Financial Literacy Measures by Way of Financial Well-Being. The Journal of Consumer Affairs. 2013, v. 47(2), 243-262. https://doi.org/10.1111/joca.12010.

SHOCKEY, S. S. Low-wealth adults financial literacy. Money management behavior and associates factors, including critical thinking. Tese, 2002, University of Utah, United States.

SZELES, M.R., FUSCO, A. Item response theory and the measurement of deprivation: evidence from Luxembourg data. Quality \& Quantity.2013, 47(3), 1545-1560 https://doi.org/10.1007/s11135-011-9607-x.

VAN ROOIJ, M. C. J, LUSARDI, A., ALESSIE, R. J. M. Financial Literacy and retirement planning in the Netherlands. Journal of Economic Psychology.2011, 32(4), 593-608.

XUE, R., GEPP, A., O'NEILL, T.J., STERN, S., VANSTONE, B.J. Financial literacy amongst elderly Australians. Accounting \& Finance. 2018, https://doi.org/10.1111/acfi.12362. 